\title{
MOTIVASI INTERNAL DAN EKSTERNAL SISWA SEKOLAH DASAR PADA PEMBELAJARAN MATEMATIKA
}

\author{
Ni Luh Sakinah Nuraini ${ }^{1}$ \\ Wisnu Cahyo Laksono ${ }^{2}$ \\ ${ }^{1}$ Universitas Negeri Malang, niluh.sakinah.fip@um.ac.id \\ ${ }^{2}$ SDN Karangnongko 1, wisnucahyo54@yahoo.com
}

\begin{abstract}
One of the factor that plays an important role in learning mathematics is motivation to learn. The purpose of this study was to determine learning motivation both internal and external motivation that play a role in student learning in the content of mathematics in SDN 1 Gawang and SDN 2 Gawang, Kebonagung District, Pacitan Regency. The results showed that the internal motivation and external motivation of students of SDN 1 Gawang and SDN 2 Gawang in learning mathematics were in the good category, based on the average scores obtained. Viewed from the supporting indicators, it is necessary to increase internal motivation related to expectations while learning and external motivation related to an adequate learning environment in mathematics learning. In addition, specifically at SDN 2 Gawang, the provision of external motivation still needs to be improved in order to optimize learning of mathematics, especially in fourth grade students.
\end{abstract}

Keywords: internal motivation, external motivation, learning motivation, mathematics learning

\begin{abstract}
Abstrak: Salah satu faktor yang memegang peranan penting dalam pembelajaran matematika adalah motivasi belajar. Tujuan penelitian ini adalah untuk mengetahui motivasi belajar baik motivasi internal maupun eksternal yang berperan dalam pembelajaran siswa pada muatan matematika di SDN 1 Gawang dan SDN 2 Gawang, Kecamatan Kebonagung, Kabupaten Pacitan. Hasil penelitian menunjukkan bahwa motivasi internal dan motivasi eksternal siswa SDN 1 Gawang dan SDN 2 Gawang dalam pembelajaran matematika berada pada kategori baik, berdasarkan rata-rata skor yang diperoleh. Dilihat pada indikator pendukungnya, maka perlu ada peningkatan motivasi internal terkait harapan saat belajar dan motivasi eksternal terkait lingkungan belajar yang memadai pada pembelajaran matematika. Selain itu, khusus di SDN 2 Gawang, pemberian motivasi eksternal masih perlu ditingkatkan agar dapat mengoptimalkan pembelajaran matematika, khususnya pada siswa kelas IV.
\end{abstract}

Kata kunci: motivasi internal, motivasi eksternal, motivasi belajar, pembelajaran matematika

Pembelajaran sebagai upaya untuk mencapai tujuan belajar yang diharapkan dapat dicapai oleh siswa. Pembelajaran merupakan suatu rangkaian peristiwa yang dirancang dan disusun sedemikian rupa sehingga dapat mendukung dan mempengaruhi terjadinya proses belajar siswa secara internal (Sanjaya, 2015). Pembelajaran dirancang sedemikian rupa sehingga siswa dibawa untuk dapat menemukan tujuan belajarnya sendiri. Guru berperan menumbuhkan asa dan motivasi 
internal siswa agar dapat menemukan pengetahuannya sendiri, mengkonstruksinya, dan juga berusaha untuk mencapai tujuan belajar yang telah dirancang sebelumnya oleh para guru (Kurniawan, 2011).

Upaya pencapaian tujuan belajar yang maksimal tentunya terdapat beberapa hal yang menjadi faktor yang berasal dari dalam diri siswa. Faktor-faktor tersebut terdiri dari 2 faktor yaitu yang pertama, faktor fisiologis (jasmaniah), dimana kondisi umum jasmani yang menandai tingkat kebugaran organ-organ tubuh yang mempengaruhi semangat dan intensitas siswa dalam mengikuti pembelajaran. Jika seorang siswa kondisi fisiknya kurang baik, maka akan menurunkan kualitas ranah cipta kognitif sehingga menyebabkan kesulitan menerima materi pembelajaran. Faktor kedua yaitu faktor psikologis. Faktor ini merupakan suatu aspek yang dapat mempengaruhi kuantitas dan kualitas perolehan belajar siswa. Faktor ini jika dipandang lebih esensial yaitu meliputi tingkat intelegensi/kecerdasan, minat, bakat, dan motivasi belajarnya (Muhibbin, 2010).

Salah satu faktor yang memegang peranan penting dalam kaitannya dengan subjek pembelajaran yaitu faktor psikologis, yang secara lebih spesifik mengenai motivasi belajar. Motivasi belajar ini sering disebut motivasi internal. Motivasi internal merupakan suatu penggerak yang berasal dari dalam diri siswa yang membuat mereka melakukan kegiatan belajar, menjamin kelangsungan kegiatan belajar, memberikan arah dalam kegiatan belajar sehingga dapat mencapai tujuan pembelajaran yang dikehendaki (Aritonang, 2008; Thaib, 2013). Motivasi internal dalam belajar siswa menjadi salah satu faktor tercapainya tujuan dalam pembelajaran. Hal ini dapat dibuktikan dengan ketercapaian siswa dalam pembelajaran, seperti melalui tes dan evaluasi. Mengetahui motivasi dalam diri siswa diperlukan karena dari beberapa indikator yang muncul apabila terdapat yang kurang sesuai dan hal itu berpengaruh terhadap hasil atau ketercapaian belajar siswa (Harianti \& Amin, 2016). Seorang guru perlu untuk meninjau kembali indikator yang dinilai kurang tersebut untuk segera diperbaiki.

Motivasi eksternal mengacu pada perilaku yang didorong oleh penghargaan eksternal seperti uang, ketenaran, nilai, dan pujian (Bourgeois, Chelazzi, \& Vuilleumier, 2016). Jenis motivasi ini muncul dari luar individu, sebagai lawan dari motivasi internal, yang berasal dari dalam individu. Orang-orang yang termotivasi secara eksternal akan terus melakukan suatu tindakan walaupun tugas itu mungkin tidak dengan sendirinya memberi imbalan (Lepper \& Greene, 2015). Tidak seperti motivasi internal, yang muncul dari dalam diri individu, motivasi eksternal difokuskan murni pada penghargaan dari luar. Motivasi eksternal biasanya didefinisikan sebagai kecenderungan untuk terlibat dalam kegiatan untuk mendapatkan semacam penghargaan eksternal. Penghargaan ini bisa berwujud atau bersifat psikologis (Suprihatin, 2015). Uang dan piala adalah contoh jenis penghargaan yang nyata. Bentuk psikologis dari motivasi eksternal dapat mencakup pujian dan pengakuan publik. 
Motivasi eksternal memiliki kecenderungan dapat mengganggu perilaku yang sebelumnya sudah berhasil dilakukan dengan motivasi instrinsik. Setelah pemberian motivasi eksternal, perilaku tersebut justru mengalami penurunan setelah motivasi eksternal dikurangi atau bahkan dihentikan. Hal ini menunjukkan bahwa penghargaan eksternal dapat menjadi alat penting dalam memotivasi perilaku, tetapi para ahli memperingatkan bahwa itu harus digunakan dengan hati-hati, terutama dengan anak-anak (Bourgeois et al., 2016). Motivasi eksternal paling baik diterapkan dalam situasi dimana siswa memiliki sedikit minat saat memulai kegiatan atau dalam kasus dimana keterampilan dasar kurang. Penghargaan ini harus dilakukan seminimal mungkin, dan harus dikaitkan langsung dengan melakukan perilaku tertentu. Setelah beberapa minat internal telah dihasilkan dan beberapa keterampilan penting telah ditetapkan, motivator eksternal harus perlahan-lahan dihapuskan (Malawi \& Kadarwati, 2018). Motivasi eksternal bukanlah hal yang buruk. Penghargaan eksternal dapat menjadi alat yang berguna dan efektif untuk membuat siswa tetap termotivasi dan terlibat aktif dalam pembelajaran (Alderman, 2013). Ini bisa sangat penting ketika siswa perlu menyelesaikan sesuatu yang mereka temukan sulit atau tidak menarik, seperti tugas pekerjaan rumah yang membosankan atau proyek yang berhubungan dengan pekerjaan yang membosankan.

Pembelajaran di SDN 1 Gawang dan SDN 2 Gawang telah menunjukkan hasil yang baik. Pembelajaran matematika di SDN 1 Gawang berada pada kategori baik dengan rata-rata hasil belajar siswa kelas IV 72,75 (SD = 3.03). Rata-rata hasil belajar siswa kelas IV pada pembelajaran matematika di SDN 2 Gawang 77,11 $(\mathrm{SD}=3,5)$. Selisih rata-rata prestasi belajar siswa kelas IV di kedua sekolah sekitar 4 poin. Hal ini menggambarkan bahwa kemampuan siswa di kedua sekolah pada pembelajaran matematika relatif setara. Dengan jumlah siswa yang tidak terlalu banyak di kelas IV pada masing-masing sekolah (8 dan 9 siswa), pelaksanaan pembelajaran matematika di kedua sekolah perlu dianalisis. Analisis dilakukan terkait faktor-faktor pendukung pembelajaran matematika, salah satunya adalah motivasi belajar. Berdasarkan permasalahan yang telah dibahas, maka dilaksanakan penelitian dengan fokus untuk mengetahui motivasi belajar baik motivasi internal maupun eksternal yang berperan dalam pembelajaran siswa pada muatan matematika di SDN 1 Gawang dan SDN 2 Gawang, Kecamatan Kebonagung, Kabupaten Pacitan. Hasil penelitian dapat digunakan sebagai rujukan untuk perbaikan indikator-indikator yang dianggap kurang berperan dalam pembelajaran siswa, khususnya pada pembelajaran matematika.

\section{METODE}

Penelitian ini termasuk dalam jenis penelitian deskriptif kuantitatif. Data dikumpulkan untuk mengetahui motivasi belajar baik dari faktor internal maupun eksternal yang berperan dalam 
pembelajaran siswa pada muatan matematika di SDN 1 Gawang dan SDN 2 Gawang, Kecamatan Kebonagung, Kabupaten Pacitan tahun ajaran 2018/2019. Populasi dalam penelitian ini yaitu seluruh siswa kelas 4 di SDN 1 Gawang $(\mathrm{N}=8)$ dan SDN 2 Gawang (N=9) pada tahun ajaran 2018/2019. Sampel yang digunakan dalam penelitian ini adalah sampel jenuh, karena menggunakan data dari keseluruhan populasi. Hal ini dikarenakan banyak siswa kelas 4 di kedua SD tersebut kurang dari 30 siswa.

Tabel 1. Indikator Angket Motivasi Belajar Siswa

\begin{tabular}{|c|c|c|}
\hline & Indikator & Keterangan \\
\hline \multirow{3}{*}{ 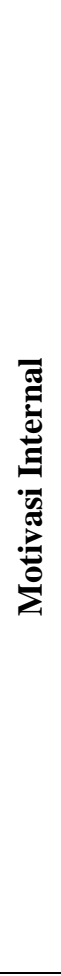 } & $\begin{array}{l}\text { Adanya hasrat } \\
\text { dan keinginan } \\
\text { berhasil }\end{array}$ & $\begin{array}{l}\text { Siswa berusaha mencari tahu sendiri hal-hal yang belum dimengerti dengan } \\
\text { bertanya kepada temannya } \\
\text { Siswa berusaha mencari tahu sendiri hal-hal yang belum dimengerti dengan } \\
\text { bertanya kepada guru } \\
\text { Siswa terus mencoba mengerjakan soal yang salah secara mandiri } \\
\text { Siswa tidak menyerah saat menemui kegagalan dalam mengerjakan soal }\end{array}$ \\
\hline & $\begin{array}{l}\text { Adanya } \\
\text { dorongan dan } \\
\text { kebutuhan } \\
\text { belajar }\end{array}$ & $\begin{array}{l}\text { Siswa melakukan diskusi aktif dengan temannya saat mendapatkan } \\
\text { permasalahan dan penugasan matematika } \\
\text { Siswa mencari tahu cara mengerjakan soal materi matematika kepada temannya, } \\
\text { tanpa diperintahkan oleh guru } \\
\text { Siswa mencari informasi yang kurang dipahami mengenai materi matematika } \\
\text { yang sedang dipelajari di buku catatan/paket } \\
\text { Siswa tidak menunjukkan penolakan/protes saat diberikan tugas tambahan } \\
\text { mengenai materi matematika yang sedang dibelajarkan }\end{array}$ \\
\hline & $\begin{array}{l}\text { Adanya harapan } \\
\text { dan cita-cita } \\
\text { dalam belajar }\end{array}$ & $\begin{array}{l}\text { Siswa aktif dan tekun dalam mempelajari materi matematika, dengan harapan } \\
\text { tidak kesulitan dalam memahami materi selanjutnya yang lebih sulit dan dapat } \\
\text { membantu teman yang lain } \\
\text { Siswa diberikan media yang menarik dengan harapan dapat memahami materi } \\
\text { matematika dengan baik } \\
\text { Siswa memperhatikan materi matematika yang disampaikan guru dengan } \\
\text { seksama } \\
\text { Siswa tidak menunjukkan sikap acuh saat diberikan materi pelajaran matematika } \\
\text { oleh guru }\end{array}$ \\
\hline \multirow{3}{*}{ 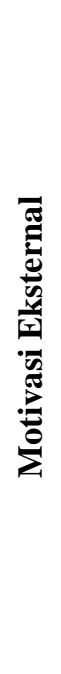 } & $\begin{array}{l}\text { Adanya } \\
\text { penghargaan } \\
\text { dalam belajar }\end{array}$ & $\begin{array}{l}\text { Siswa mendapat penghargaan berupa perkataan lisan/pujian } \\
\text { Siswa mendapat penghargaan berupa gerakan tubuh/mengacungkan jepol, } \\
\text { menepuk bahu, dll. } \\
\text { Siswa mendapat penghargaan berupa hadiah/benda } \\
\text { Siswa mendapat pengharaan berupa tanda penghargaan/simbol bintang, angka, } \\
\text { dll }\end{array}$ \\
\hline & $\begin{array}{l}\text { Adanya } \\
\text { kegiatan yang } \\
\text { menarik dalam } \\
\text { belajar }\end{array}$ & $\begin{array}{l}\text { Siswa dibelajarkan dengan kegiatan yang menyenangkan } \\
\text { Siswa dibelajarkan dengan kegiatan demonstrasi } \\
\text { Siswa dibelajarkan dengan kegiatan diskusi } \\
\text { Siswa dibelajarkan dengan media yang menarik }\end{array}$ \\
\hline & $\begin{array}{l}\text { Adanya } \\
\text { lingkungan } \\
\text { belajar yang } \\
\text { kondusif }\end{array}$ & $\begin{array}{l}\text { Lingkungan belajar siswa di kelas cukup nyaman dan kondusif } \\
\text { Media yang digunakan guru cukup lengkap dan menarik } \\
\text { Sumber belajar yang tersedia cukup lengkap } \\
\text { Terpisahnya muatan matematika dari tematik menambah kedalaman materi } \\
\text { siswa }\end{array}$ \\
\hline
\end{tabular}


Pengumpulan data yang dilakukan dalam penelitian ini menggunakan angket sebagai intrumen untuk mengumpulkan data motivasi belajar siswa. Selain angket, untuk mengkonfirmasi motivasi dalam pembelajaran matematika di kelas, dilakukan observasi selama pelaksanaan pembelajaran matematika. Lembar observasi disesuaikan dengan indikator motivasi internal dan eksternal yang telah ditentukan. Angket yang digunakan dalam pengumpulan data berupa angket tertutup dengan pilihan jawaban yang sudah disediakan dalam skala Likert dengan skor $1-5$. Skor 1 untuk pilihan "Sangat Tidak Setuju" hingga skor 5 untuk pilihan "Sangat Setuju". Indikator angket mengadaptasi indikator motivasi internal dan eksternal yang telah ada sebelumnya (Uno, 2010). Dalam pengisian angket, siswa diminta untuk memilih pilihan jawaban yang dianggap paling sesuai dengan keadaan dirinya. Setelah itu, data dianalisis dengan teknik analisis statistik deskriptif. Kisi-kisi angket motivasi belajar dapat dilihat pada Tabel 1.

\section{HASIL DAN PEMBAHASAN}

Hasil analisis menunjukkan bahwa siswa di kedua sekolah memiliki motivasi belajar yang cenderung sama pada pembelajaran matematika (Gambar 1). Berdasarkan rata-rata skor pada setiap indikator, motivasi eksternal yang dirasakan siswa selama pembelajaran matematika berada pada kriteria baik untuk indikator penghargaan dan kegiatan menarik selama pembelajaran. Sementara itu, pada indikator lingkungan belajar, rata-rata skor motivasi masih berada pada kriteria cukup.

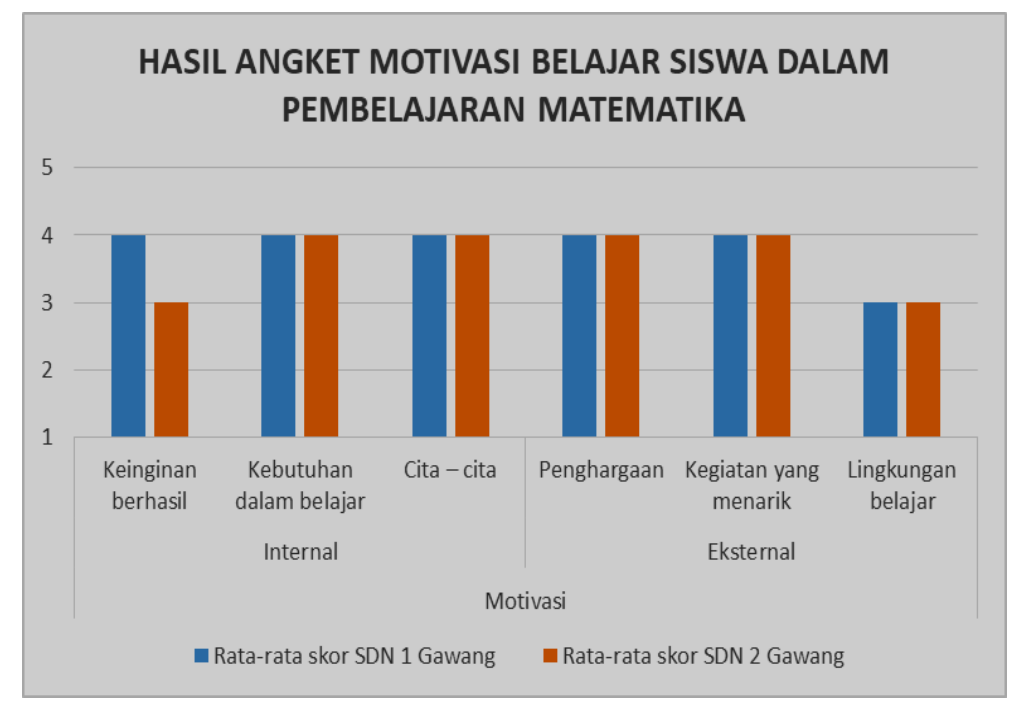

Gambar 1. Hasil Angket Motivasi Belajar Siswa

Pada indikator motivasi internal, hasil yang berbeda terlihat pada indikator keinginan untuk berhasil pada siswa selama pembelajaran matematika. Pada SDN Gawang 1, siswa berada pada kriteria baik, sementara pada SDN Gawang 2, siswa berada pada kriteria 
cukup. Keingian untuk berhasil dalam matematika dipengaruhi oleh faktor-faktor terkait kemampuan siswa dalam belajar matematika. Salah satu faktor tersebut adalah selfefficacy. Self-efficacy dalam matematika menunjukkan kepercayaan diri siswa pada kemampuan mereka untuk mengatasi kesulitan atau hambatan untuk memecahkan masalah matematika. Keyakinan semacam itu telah terbukti penting bagi motivasi, karena keyakinan bahwa siswa akan dapat menyelesaikan masalah adalah awal untuk siswa dapat memberikan waktu dan upaya yang diperlukan untuk mengatasinya (Skaalvik, Federici, \& Klassen, 2015).

Indikator lainnya terkait motivasi internal menunjukkan rata-rata skor yang sama, yaitu pada kriteria baik. Indikator terkait kebutuhan belajar dan harapan siswa dalam belajar matematika, membuktikan bahwa adanya kesadaran siswa bahwa matematika merupakan pelajaran yang penting bagi siswa. Hal ini sangat baik sebagai landasan bagi siswa belajar matematika pada jenjang berikutnya. Disamping itu, pada kenyataannya belajar matematika perlu dilakukan bukan hanya untuk sekolah, tetapi juga dalam penerapannya di kehidupan sehari-hari.

Pada indikator terkait motivasi eksternal, menunjukkan adanya kriteria yang sama pada dua SD tersebut. Indikator terkait kegiatan pembelajaran yang menarik berada pada kategori baik. Dalam mencoba mencapai suatu tujuan pembelajaran, semakin siap dalam perencanaan, semakin memuaskan hasilnya (Sanjaya, 2015). Satu cara pasti untuk menerapkan hal ini dalam pembelajaran adalah membantu siswa untuk mencapai tujuan yang ingin dicapai dengan semangat. Masalah sebenarnya dalam memotivasi siswa saat belajar adalah menemukan nilai-nilai yang cukup kuat untuk merangsang siswa agar melakukan upaya yang efektif (Daly, Bourgaize, \& Vernitski, 2019).

Nilai yang sangat menarik bagi satu individu mungkin sedikit menarik, bahkan tidak menarik sama sekali bagi individu lain. Selain itu, nilai-nilai yang sangat menarik bagi satu individu pada satu waktu mungkin tidak begitu menarik pada waktu yang lain. Guru harus terus berusaha untuk memahami perbedaan dan perubahan ini karena semua peserta didik tidak bereaksi sama. Oleh karena itu, rancangan pembelajaran yang menarik akan membantu meningkatkan motivasi belajar siswa. Motivasi belajar harus bervariasi untuk individu yang berbeda (Bourgeois et al., 2016). Pemahaman tentang sifat motivasi itu penting, karena motivasi menentukan, tidak hanya intensitas upaya untuk belajar, tetapi juga sejauh mana upaya ini dilakukan sebagai keseluruhan pendukung aktivitas belajar. Motivasi belajar membantu siswa untuk berkonsentrasi pada apa yang dia lakukan, dan dengan demikian 
untuk mendapatkan kepuasan (Suprihatin, 2015). Motivasi berkelanjutan diperlukan untuk membantu peserta didik berkonsentrasi pada pembelajaran yang akan dipelajari.

Kedua SD juga menunjukkan kategori cukup pada aspek motivasi terkait lingkungan belajar. Lingkungan belajar yang mendukung dalam pembelajaran matematika perlu dikembangkan untuk mengoptimalkan pembelajaran matematika siswa. Ketersediaan sumber belajar yang memadai, adanya media pembelajaran hingga ruang kelas yang nyaman menjadi bagian tak terpisahkan dari indikator ini. Kurang maksimalnya lingkungan belajar di kedua sekolah memberikan gambaran perlunya kerjasama berbagai pihak untuk mengoptimalkan unsur-unsur tersebut.

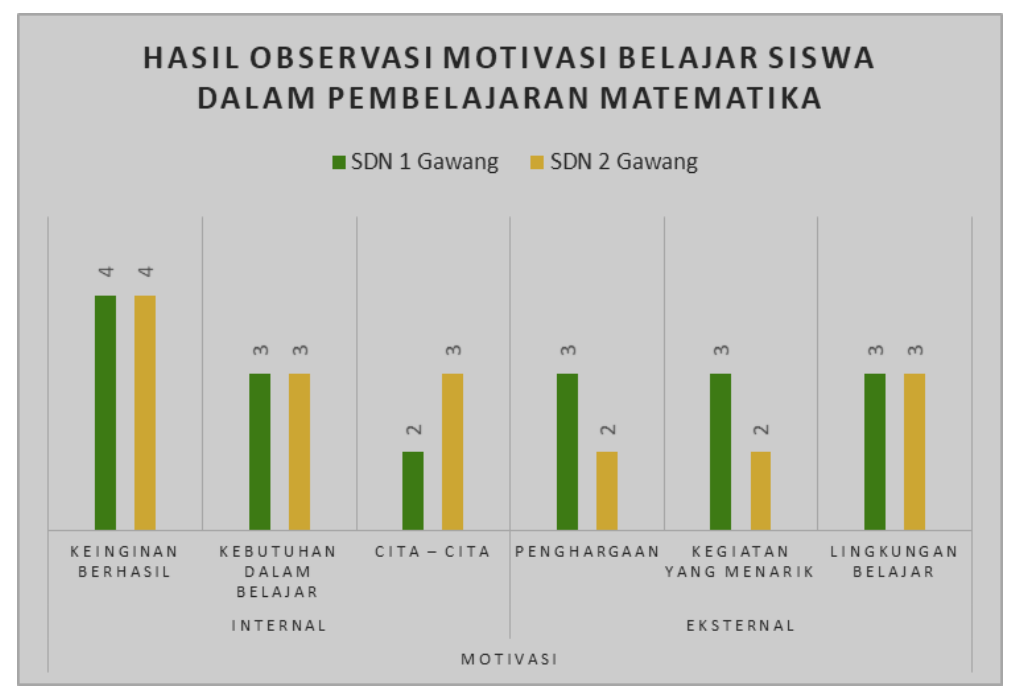

Gambar 2. Hasil Observasi Motivasi Belajar Siswa

Hasil observasi menunjukkan bahwa motivasi belajar siswa pada pembelajaran matematika di SDN 1 Gawang berada pada kriteria "Baik". Hal ini sesuai dengan hasil angket siswa. Namun sebaliknya, pada beberapa indikator motivasi di SDN 2 Gawang, ada perbedaan signifikan antara hasil observasi dan angket. Perbedaan pada beberapa indikator tersebut, menunjukkan perlunya upaya peningkatan motivasi siswa terkait dengan adanya harapan dan cita-cita, pemberian penghargaan serta kegiatan menarik selama pembelajaran matematika. Hasil observasi motivasi siswa kelas IV selama pembelajaran matematika di kedua SD ditunjukkan pada Gambar 2.

Berdasarkan hasil analisis terhadap indikator-indikator terkait motivasi internal dan eksternal, nampak bahwa kedua sekolah, SDN 1 Gawang dan SDN 2 Gawang, memiliki ratarata skor untuk setiap indikator, yang relatif sama (Gambar 1). Jika dibandingkan dengan hasil observasi, maka pada SDN 2 Gawang, motivasi eksternal yang diberikan pada siswa 
pada pembelajaran matematika masih belum maksimal. Sebaliknya, pada motivasi internal siswa SDN 1 Gawang, terdapat indikator terkait harapan saat belajar yang perlu dioptimalkan.

Apabila dilihat dari prestasi belajar siswa, maka dengan motivasi internal yang lebih tinggi serta motivasi eksternal yang lebih sedikit, hasil belajar matematika siswa di SDN 2 Gawang $(M=77,11)$ memiliki rata-rata yang lebih tinggi dari siswa di SDN 1 Gawang $(M=$ 72,75). Jelas bahwa motivasi internal memiliki pengaruh yang cukup besar terhadap prestasi belajar matematika siswa. Dalam pembelajaran matematika, motivasi dapat memberikan 93,1 \% pengaruh terhadap prestasi belajar matematika siswa (Cleopatra, 2015). Dilihat dari motivasi internal, kecemasan terhadap matematika, kemandirian belajar, regulasi diri, selfefficacy juga memiliki pengaruh signifikan terhadap prestasi belajar matematika siswa (Lomu \& Widodo, 2018; Solikah, 2012).

Tujuan dan pentingnya motivasi harus dipahami dengan jelas oleh guru. Tujuan mendasar dari motivasi adalah untuk merangsang dan memfasilitasi kegiatan belajar (Suprihatin, 2015). Belajar adalah proses aktif yang perlu dimotivasi dan dibimbing menuju akhir yang diinginkan. Belajar adalah inisiatif sendiri, tetapi harus dibantu oleh motif tertentu sehingga pembelajar akan bertahan dalam kegiatan belajar (Alderman, 2013). Motif tersebut pasti berarti dalam setiap hal, karena adanya motif ini dapat memunculkan kesiapan belajar siswa. Semakin siap siswa untuk belajar, semakin besar perhatian yang diberikan pada pelajaran yang ada, dan semakin cepat tujuan pembelajaran dapat tercapai.

Penelitian-penelitian sebelumnya menunjukkan bahwa motivasi belajar berhubungan dengan persepsi siswa, harapan siswa dalam belajar, dukungan guru dan lingkungan belajar, serta adanya penghargaan dalam pembelajaran (Daly et al., 2019; Farhan \& Retnawati, 2014; Gladstone, Häfner, Turci, Kneißler, \& Muenks, 2018). Motivasi dalam belajar juga terkait dengan adanya pengaruh dari dalam diri dan diluar siswa. Hal inilah yang kemudian terbagi dalam dua jenis motivasi belajar, yaitu motivasi internal dan motivasi eksternal. Dalam belajar, motivasi internal dan eksternal memiliki peran yang berbeda tetapi tujuan yang sama, yaitu memberikan pengaruh terhadap aktivitas belajar (Hannula, 2006).

Motivasi eksternal muncul ketika siswa termotivasi melakukan suatu hal untuk memperoleh penghargaan atau menghindari hukuman. Dalam motivasi ini, siswa tidak terlibat dalam suatu kegiatan belajar karena mereka memang menikmati pembelajaran tersebut, tetapi ada keinginan untuk mendapatkan imbalan atau menghindari hal yang tidak diinginkan. Motivasi internal berlaku sebaliknya. Tanpa adanya suatu penghargaan, siswa tergerak untuk terlibat dalam kegiatan belajar karena memang mereka menginginkannya. Adanya dorongan untuk tetap terlibat dalam kegiatan pembelajaran ini menunjukkan bahwa siswa memang menyadari bahwa hal tersebut merupakan kebutuhan mereka. 
Selain motivasi internal, motivasi eksternal juga berpengaruh dalam prestasi belajar matematika. Sebagai materi yang cenderung sulit bagi siswa, adanya motivasi eksternal dibutuhkan agar membangkitkan semangat siswa untuk memulai pembelajaran (Prast, Van de Weijer-Bergsma, Miočević, Kroesbergen, \& Van Luit, 2018). Kondisi yang ditemukan pada siswa kelas IV SDN 1 Gawang dan SDN 2 Gawang ini telah memperjelas indikator yang perlu dioptimalkan pada pembelajaran matematika. Akan tetapi, hubungan antara kedua motivasi ini terhadap prestasi siswa pada pembelajaran matematika siswa di sekolah dasar, perlu dikaji kembali secara lebih mendalam.

\section{SIMPULAN DAN SARAN}

\section{Simpulan}

Motivasi internal dan motivasi eksternal siswa SDN 1 Gawang dan SDN 2 Gawang dalam pembelajaran matematika berada pada kategori baik, berdasarkan rata-rata skor yang diperoleh. Dilihat pada indikator pendukungnya, maka perlu ada peningkatan motivasi internal terkait harapan saat belajar dan motivasi eksternal terkait lingkungan belajar yang memadai pada pembelajaran matematika. Selain itu, khusus di SDN 2 Gawang, pemberian motivasi eksternal masih perlu ditingkatkan agar dapat mengoptimalkan pembelajaran matematika khususnya pada siswa kelas IV.

\section{Saran}

Sebagai tindak lanjut dari penelitian ini, perlu dikaji lebih mendalam hubungan antara motivasi internal dan eksternal terhadap prestasi belajar siswa. Indikator-indikator terkait kedua motivasi ini juga perlu dikembangkan disesuaikan dengan kondisi siswa dan perkembangan pembelajaran matematika di sekolah dasar.

\section{DAFTAR RUJUKAN}

Alderman, M. K. (2013). Motivation for achievement: Possibilities for teaching and learning. Routledge.

Aritonang, K. T. (2008). Minat dan motivasi dalam meningkatkan hasil belajar siswa. Jurnal Pendidikan Penabur, 7(10), 11-21.

Bourgeois, A., Chelazzi, L., \& Vuilleumier, P. (2016). How motivation and reward learning modulate selective attention. In Progress in brain research (Vol. 229, pp. 325-342). Elsevier.

Cleopatra, M. (2015). Pengaruh gaya hidup dan motivasi belajar terhadap prestasi belajar matematika. Formatif: Jurnal Ilmiah Pendidikan MIPA, 5(2).

Daly, I., Bourgaize, J., \& Vernitski, A. (2019). Mathematical mindsets increase student motivation: Evidence from the EEG. Trends in Neuroscience and Education, 15, 18-28. https://doi.org/10.1016/j.tine.2019.02.005

Farhan, M., \& Retnawati, H. (2014). Keefektifan PBL dan IBL ditinjau dari prestasi belajar, kemampuan representasi matematis, dan motivasi belajar. Jurnal Riset Pendidikan Matematika, 1(2), 227-240.

Gladstone, J. R., Häfner, I., Turci, L., Kneißler, H., \& Muenks, K. (2018). Associations between parents and students' motivational beliefs in mathematics and mathematical performance: The role of gender. Contemporary Educational Psychology, 54, 221-234. https://doi.org/10.1016/j.cedpsych.2018.06.009

Hannula, M. S. (2006). Motivation in mathematics: Goals reflected in emotions. Educational Studies in Mathematics, 63(2), 165-178. 
Harianti, R., \& Amin, S. (2016). Pola asuh orangtua dan lingkungan pembelajaran terhadap motivasi belajar siswa. Curricula: Journal of Teaching and Learning, 1(2).

Kurniawan, A. (2011). Implementasi metode pembelajaran inquiry terbimbing dan inquiry bebas termodifikasi terhadap prestasi belajar biologi ditinjau dari kemampuan awal dan keingintahuan siswa (Studi Kasus pada Pokok Bahasan Sistem Respirasi Kelas XI IPA SMA Negeri 2 Sragen (PhD Thesis). UNS (Sebelas Maret University).

Lepper, M. R., \& Greene, D. (2015). The hidden costs of reward: New perspectives on the psychology of human motivation. Psychology Press.

Lomu, L., \& Widodo, S. A. (2018). Pengaruh Motivasi Belajar Dan Disiplin Belajar Terhadap Prestasi Belajar Matematika Siswa. Prosiding Seminar Nasional Pendidikan Matematika Etnomatnesia.

Malawi, I., \& Kadarwati, A. (2018). Pembaharuan Pembelajaran di Sekolah Dasar. CV. AE MEDIA GRAFIKA.

Muhibbin, S. (2010). Psikologi pendidikan dengan pendekatan baru. Bandung: PT Remaja Rosdakarya.

Prast, E. J., Van de Weijer-Bergsma, E., Miočević, M., Kroesbergen, E. H., \& Van Luit, J. E. H. (2018). Relations between mathematics achievement and motivation in students of diverse achievement levels. Contemporary Educational Psychology, 55, 84-96. https://doi.org/10.1016/j.cedpsych.2018.08.002

Sanjaya, W. (2015). Perencanaan dan desain sistem pembelajaran. Kencana.

Skaalvik, E. M., Federici, R. A., \& Klassen, R. M. (2015). Mathematics achievement and self-efficacy: Relations with motivation for mathematics. International Journal of Educational Research, 72, 129 136. https://doi.org/10.1016/j.ijer.2015.06.008

Solikah, M. (2012). Pengaruh kecemasan siswa pada matematika dan motivasi belajar terhadap prestasi belajar matematika. MATHEdunesa, l(1).

Suprihatin, S. (2015). Upaya guru dalam meningkatkan motivasi belajar siswa. Jurnal Pendidikan Ekonomi UM Metro, 3(1), 73-82.

Thaib, E. N. (2013). Hubungan Antara prestasi belajar dengan kecerdasan emosional. JURNAL ILMIAH DIDAKTIKA: Media Ilmiah Pendidikan Dan Pengajaran, 13(2).

Uno, H. B. (2010). Teori Motivasi dan Pengukurannya. Jakarta: Bumi Aksara. 